\title{
Implementation of Best Management Practices to Reduce Agricultural Total Maximum Daily Loads in the Calleguas Creek and Santa Clara River Watersheds: A Case Study of Water Contaminant Mitigation in California
}

\author{
Donald J. Merhaut ${ }^{1}$, Lea Corkidi, Maren Mochizuki, and Toan Khuong \\ Department of Botany and Plant Sciences, University of California, 4118 Batchelor Hall, Riverside, CA 92521
}

Julie Newman, Ben Faber, and Oleg Daugovish

University of California Cooperative Extension Ventura County, 669 County Square Drive, Suite 100,

Ventura, CA 93003

\author{
Sonya Webb \\ Ventura County Resource Conservation District, 3380 Somis Road, Somis, CA 93066 \\ Additional index words. agriculture, California, conditional waiver, Ventura County, waste discharge requirements
}

\begin{abstract}
Agriculture is a major industry in California, with cool-season crops grown along the state's coasts, warm-season crops grown in the hot deserts, and many temperate crops grown in the state's valleys. In coastal communities such as Ventura County, the Calleguas Creek and the Santa Clara River watersheds have 50,000 and 60,000 irrigated acres of farm crops, respectively. These watersheds are considered impaired by nutrients, salts, pesticides, and other agricultural contaminants. Mitigation of chemical and sediment runoff through grower-implemented best management practices (BMPs) is therefore one of the highest priorities in the Los Angeles Regional Water Quality Control Board Basin Plan. A 3year project was designed to assist Ventura County growers in meeting regional water quality objectives. The University of California Cooperative Extension Ventura County and the University of California, Riverside, collaborated with the Ventura County Resource Conservation District and the Ventura County Agricultural Irrigated Lands Group (VCAILG) to address three project goals: increase grower and landowner understanding of local agricultural water quality issues; identify gaps or deficiencies in current management practices in agricultural operations; and reduce the contribution of nutrients, pesticides, and other pollutants to impaired water bodies. To achieve these goals, 469 surveys of agricultural water quality management practices were collected to assess the extent of current adoption of BMPs. Over 160 growers who farm more than 14,000 acres that drain into Calleguas Creek and 7,000 acres that drain into the Santa Clara River watersheds were assisted. Using the survey, growers developed site-specific farm water quality plans and received on-farm recommendations for BMPs. Additionally, 12 water quality educational programs, "including demonstrations of successful BMPs," were developed and more than 2500 copies of educational materials published by the University of California, the Resource Conservation District, and the Natural Resources Conservation Service of the U.S. Department of Agriculture were distributed at on-farm visits, workshops, and other grower events. The project resulted in improved understanding, by growers and landowners, of water quality issues and significantly increased the implementation of appropriate on-farm BMPs to protect water quality. Nearly 100 new BMPs primarily aimed at managing erosion, sediment movement, and irrigation runoff were identified and documented through annual reassessments for more than 8000 acres draining into Calleguas Creek. A total of 518 people attended the educational programs, and over $90 \%$ of participants who completed evaluations rated the programs highly. In the final year of the project, $75 \%$ of attendees indicated they plan to implement new BMPs within the next 5 years, especially in the areas of irrigation, erosion, and pest management.
\end{abstract}

Like other parts of the United States, impairment of water quality by agriculture is a major concern in California. In Ventura County, the Calleguas Creek (Fig. 1) and the Santa Clara River (Fig. 2) watersheds have 50,000 and 60,000 irrigated agricultural acres, respectively. These watersheds are considered impaired by agricultural contaminants such as nutrients, salts, and pesticides (U.S. Environmental Protection Agency, 2013). In

Received for publication 2 Apr. 2013. Accepted for publication 30 June 2013.

This paper was part of the colloquium "Regulating Water Quality: Current Legislation, Future Impacts" held 1 Aug. 2012 at the ASHS Conference, Miami, FL, and sponsored by the Nursery Crops, Water Utilization and Management, Waste Utilization in Horticulture, and Floriculture Working Group.

${ }^{1}$ To whom reprint requests should be addressed; e-mail donald.merhaut@ucr.edu.
1967, California formed the State Water Resources Control Board (SWRCB, 2013) to oversee that the state maintains water quality and properly allocates its water sources for beneficial uses. The SWRCB developed nine Regional Water Quality Control Boards (RWQCBs). Each of these agencies is responsible for developing and enforcing water quality plans in their region, taking into consideration their region's differences in climate and water uses. The Calleguas Creek and Santa Clara River watersheds are under the jurisdiction of Region 9, the Los Angeles RWQCB. The Los Angeles RWQCB adopted a Conditional Waiver of Waste Discharge Requirements for those that discharge water from irrigated agricultural land (California State Water Resources Control Board, 2013). The current "Conditional Ag Waiver" for this region was adopted in Oct. 2010 and lasts for 5 years. The program requires that either individual land managers or "discharge groups" such as farmers for a particular stream reach monitor water draining from irrigated agricultural land and implement additional BMPs as necessary to reduce nutrient and pesticide runoff. They must also complete 8 hours of farm water quality education (California Regional Water Quality Control Board, 2013; Newman, 2011).

A 3-year project was designed to assist Ventura County growers in meeting the regional water quality objectives. The cooperators in this project addressed three main goals: increase farmer and landowner understanding of local agricultural water quality issues; identify gaps or deficiencies in current management practices in agricultural operations; and reduce the contribution of nutrients, pesticides, and other pollutants to impaired water bodies. To achieve these goals, the project included: the dissemination of self-assessment questionnaires, documentation of current BMPs, and education and outreach to targeted grower groups. 


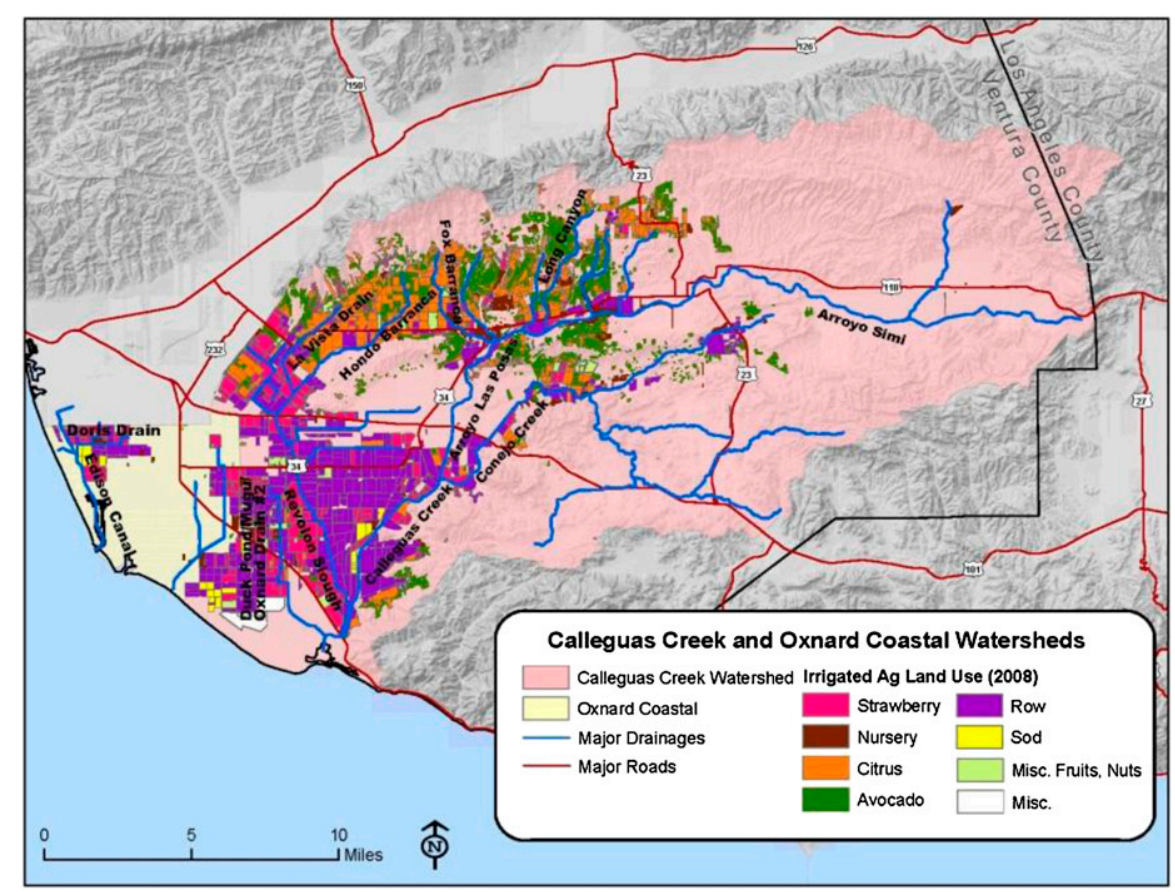

Fig. 1. Calleguas Creek watershed agricultural land use map (Ventura County Agriculture Irrigated Lands Group, 2010).

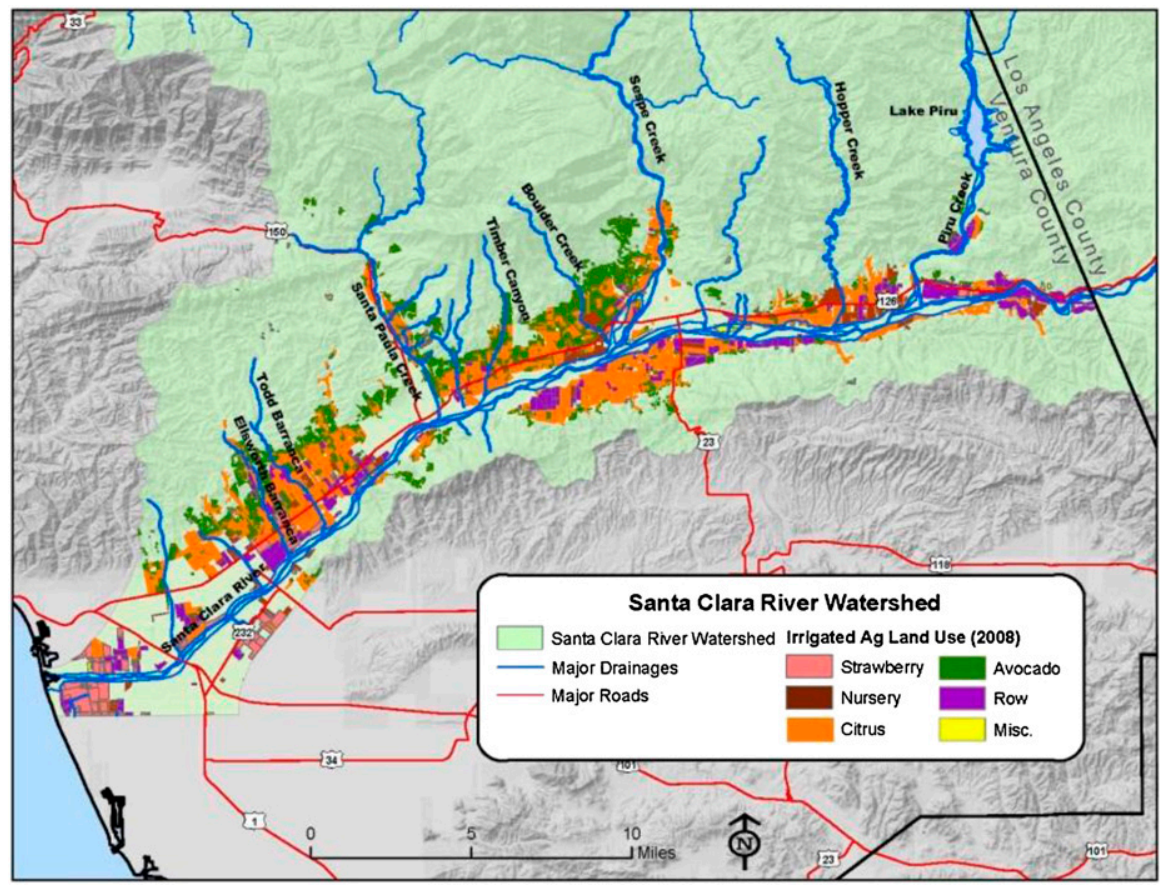

Fig. 2. Santa Clara River watershed agricultural land use map (Ventura County Agriculture Irrigated Lands Group, 2010)

\section{DISSEMINATION OF SELF- ASSESSMENT QUESTIONNAIRES}

To gather information about BMP use in the Calleguas Creek and Santa Clara watersheds, a survey of water quality management practices for agriculture was developed and distributed to growers in Ventura County at the beginning of 2009 by the VCAILG. VCAILG is a voluntary program consisting of growers and landowners. This group is managed under the Farm Bureau of Ventura County but is funded through annual assessments to its members. The role of VCAILG is to hire consultants who will establish watermonitoring sites, collect and submit runoff water samples to independent laboratories for analyses, and report results to the appropriate state water agencies (Farm Bureau of Ventura County, 2013). The survey included questions regarding 100 individual BMPs, which were classified into the following categories: sediment and erosion management, irrigation management, pest management, nutrient management, salinity management and leaching, and property management (Ventura County Agriculture Irrigated Lands Group, 2008). Surveys were mailed to landowners within VCAILG's first-tier priority and second-tier priority drainage areas on Mar. 2009 and Oct. 2009, respectively. These priority drainage areas were classified as first, second, or third tier based on the total number of benchmark exceedances, the number of classes of pollutants, the number of total maximum daily loads effective at the drainage point, and the percentage of agricultural acreage enrolled in the VCAILG. Drainages included in the first priority area were Oxnard Central Ditch (Oxnard Coastal watershed), La Vista Drain (Calleguas Creek watershed), and Todd Barranca and Piru Creek (Santa Clara River watershed) (Figs. 1 and 2). Drainages included in the second priority area were Mugu Lagoon, Revolon Slough, and Calleguas Creek (Calleguas Creek watershed) (Fig. 1).

Four hundred twenty-nine surveys that described management practices on the irrigated land were completed and returned. BMPs were evaluated for the constituents that produced water quality benchmark exceedances during VCAILG monitoring in 2007 and 2008. Monitoring data collected by VCAILG to characterize conditions in Calleguas Creek before project implementation indicated that most exceedances of water quality benchmarks were the result of nitrate, organochlorine (forms of DDT, chlordane, and toxaphene), and organophosphorus pesticides (diazinon and chlorpyrifos) as well as salts at some sites (Ventura County Agriculture Irrigated Lands Group, 2010). Results of the surveys (2009 benchmark data) indicate that growers implemented new BMPs after Jan. 2008 in all of the priority drainages areas where exceedances occurred; however, some BMP categories had not been implemented for specific targeted constituents at this time. BMPs designed for sediment/erosion management and salinity/leaching management were less widely implemented in the priority drainages than BMPs designed for management of irrigation, pests, nutrients, and property. Property management was the most prevalent BMP category in use in the priority drainages with an overall average use of $98 \%$ for each priority constituent (nitrogen, organochlorine, and organophosphorus pesticides) across the second-tier priority areas (Table 1).

\section{DOCUMENTATION OF BEST MANAGEMENT PRACTICES}

Between 1 May 2009 and 31 Mar. 2012, 161 farmers and landowners farming 14,287 acres draining to the Calleguas Creek watershed and 7,304 acres draining to the Santa Clara River watershed were assisted with onsite farm water quality management planning (Table 2). Based on site conditions such as 
Table 1. Percentage of acreage within the Calleguas Creek and Santa Clara watersheds where best management practices (BMPs) were implemented to mitigate benchmark exceedances of nitrate, organochlorine, and organophosphorus pesticides ( $\mathrm{n}=429$ surveys) in 2009 (Ventura County Agriculture Irrigated Lands Group, 2010). ${ }^{\mathrm{z}}$

\begin{tabular}{|c|c|c|c|c|c|c|}
\hline \multirow[b]{3}{*}{ Best Management Practice } & \multicolumn{6}{|c|}{ Percentage of surveyed acreage (\%) } \\
\hline & \multicolumn{2}{|c|}{ Nitrate $^{y}$} & \multicolumn{2}{|c|}{ Organochlorine pesticides ${ }^{x}$} & \multicolumn{2}{|c|}{ Organophosphorus pesticides ${ }^{\mathrm{w}}$} \\
\hline & First priority ${ }^{\mathrm{v}}$ & Second priority $^{u}$ & First priority & Second priority & First priority & Second priority \\
\hline Erosion and sediment & $63^{t}$ & 50 & 63 & 58 & 64 & 54 \\
\hline Irrigation & 87 & 86 & 83 & 86 & 83 & 86 \\
\hline Pest & N/A & $\mathrm{N} / \mathrm{A}$ & $\mathrm{N} / \mathrm{A}$ & N/A & 93 & 98 \\
\hline Nutrients & 88 & 94 & $\mathrm{~N} / \mathrm{A}$ & $\mathrm{N} / \mathrm{A}$ & N/A & N/A \\
\hline Salinity & 71 & 93 & $\mathrm{~N} / \mathrm{A}$ & $\mathrm{N} / \mathrm{A}$ & N/A & $\mathrm{N} / \mathrm{A}$ \\
\hline Property & 95 & 98 & 96 & 98 & 90 & 92 \\
\hline
\end{tabular}

${ }^{\mathrm{z}}$ Acreage percentage is presented by BMP type and targeted constituents.

yitrate benchmark is $10 \mathrm{mg} \cdot \mathrm{L}^{-1}$.

${ }^{\mathrm{x}} 4,4$-DDT compounds benchmark is $0.00059 \mu \mathrm{g} \cdot \mathrm{L}^{-1}$.

${ }^{\text {w}}$ Chlorpyrifos benchmark is $0.025 \mu \mathrm{g} \cdot \mathrm{L}^{-1}$. Diazinon benchmark is $0.1 \mu \mathrm{g} \cdot \mathrm{L}^{-1}$.

${ }^{v}$ Drainages included in the first priority area: Oxnard Central Ditch (Oxnard Coastal watershed), La Vista Drain (Calleguas Creek watershed), and Todd Barranca and Piru Creek (Santa Clara River watershed).

urainages included in the second priority area: Mugu Lagoon, Revolon Slough, and Calleguas Creek (Calleguas Creek watershed).

'For details on acreage calculations (Ventura County Agriculture Irrigated Lands Group, 2010).

$\mathrm{N} / \mathrm{A}=$ not applicable.

Table 2. Number of acres impacted with on-site water quality management plans in the Calleguas Creek and Santa Clara River watersheds from May 2009 to Mar. 2012 based on surveys conducted with growers and landowners during this time period. ${ }^{\mathrm{z}}$

\begin{tabular}{lrcrrr}
\hline & \multicolumn{2}{c}{ Calleguas Creek } & & \multicolumn{2}{c}{ Santa Clara River } \\
\cline { 2 - 3 } \cline { 5 - 6 } Crop & $\begin{array}{r}\text { Acreage } \\
\text { assisted }\end{array}$ & $\begin{array}{r}\text { Percentage of total agricultural } \\
\text { acreage assisted in watershed }\end{array}$ & & $\begin{array}{c}\text { Acreage } \\
\text { assisted }\end{array}$ & $\begin{array}{c}\text { Percentage of total agricultural } \\
\text { acreage assisted in watershed }\end{array}$ \\
\hline Orchard & 3,671 & $26 \%$ & 3,809 & $52 \%$ \\
Nursery & 64 & $1 \%$ & 1,457 & $20 \%$ \\
Row & 5,343 & $22 \%$ & 333 & $5 \%$ \\
Strawberry & 3,129 & $15 \%$ & 1,565 & $21 \%$ \\
Other berries & 2,080 & & 140 & $2 \%$ \\
Total & 14,287 & & 7,304 & \\
\hline
\end{tabular}

${ }^{\mathrm{z}}$ Data are presented by crop type.

topography, microclimate, and crop type, various types of BMPs were suggested during these consultations. Most recommendations included sediment and erosion management practices and irrigation management practices. During the 3-year project period, newly implemented BMPs were documented on 53 properties in the Calleguas Creek watershed, representing over 9800 acres (Table 3). This acreage represents $18 \%$ of the estimated agricultural acreage in the watershed (the total acreage of Calleguas Creek watershed is 219,520 acres with an estimated $25 \%$ in agricultural land use). Various BMPs were implemented with irrigation management being implemented in all stream reaches (Table 4). Some growers expressed that more efficient irrigation management during the dry season would result in reduced runoff, because most runoff during the dry season results from improper irrigation. Growers on level terrain close to sea level often installed tile drains and pumps to reduce water levels on their fields, so improved irrigation management would minimize additional tile drain pumping. Sediment and erosion management was also frequently implemented by growers.

\section{EDUCATION AND OUTREACH}

Twelve educational programs were developed and conducted. These programs included classroom lectures and demonstrations and tours of farms showcasing successful BMP implementation. Meetings were open to growers in all Ventura County watersheds as well as growers in other counties. The educational programs were also used by VCAILG members and farmers from other agricultural areas to obtain "Ag Waiver" credits. Each workshop included a survey to assess whether the information presented was useful in implementing BMPs. Additionally, more than 2500 copies of several educational materials published by the University of California, the Resource Conservation District, and the Natural Resources Conservation Service of the U.S. Department of Agriculture were distributed at on-farm visits, workshops, and other grower events to enhance adoption of BMPs.

Over $55 \%$ of meeting attendees completed program evaluations when averaged for all 12 workshops. Over $90 \%$ of these attendees rated the workshops and tours as "informative," the highest rating of the choices provided. At eight workshops conducted between May 2009 and June 2011, attendees were asked whether participating in a previous educational program resulted in implementation of a BMP; over $55 \%$ of respondents indicated this was the case. Irrigation and property management BMPs were among the most widely adopted after attending an education meeting. Beginning in June 2011, attendees were asked about
Table 3. Number of properties and total acreage in which best management practices were implemented between May 2009 and Mar. 2012 based on surveys conducted with growers and landowners during this time period. ${ }^{\mathrm{z}}$

\begin{tabular}{lcc}
\hline $\begin{array}{l}\text { Calleguas Creek } \\
\text { stream reach }\end{array}$ & $\begin{array}{c}\text { Number of } \\
\text { properties }\end{array}$ & Acreage \\
\hline Mugu Lagoon & 2 & 625 \\
Calleguas Creek 2 & 6 & 393 \\
Calleguas Creek 3 & 1 & 9 \\
Revolon Slough & 10 & 4751 \\
Beardsley Channel & 12 & 1431 \\
Arroyo Las Posas & 13 & 965 \\
Conejo Creek A & 2 & 53 \\
Conejo Creek B & 4 & 98 \\
Arroyo Santa Rosa & 3 & 8 \\
Total & 53 & 8333 \\
\hline
\end{tabular}

${ }^{\mathrm{z}}$ Data are presented by stream reach in the Calleguas Creek watershed.

planned BMP implementation as a result of attending the meeting being evaluated. Approximately $75 \%$ of respondents indicated they would adopt new BMPs in the next 5 years, particularly for irrigation, erosion, and pest management. The results of program evaluations highlight the importance of educational workshops and tours. Not only were these meetings rated highly by growers, property managers, and other affiliates, but attendance also led to immediate implementation of BMPs as well as future plans for further BMP adoption.

\section{CONCLUSIONS}

This 3-year, collaborative project resulted in improved understanding, by growers and landowners, of water quality issues and significantly increased the implementation of appropriate BMPs to protect water quality. Nearly 100 new BMPs, primarily aimed at managing erosion, sediment movement, and irrigation runoff in more than 8000 acres draining into Calleguas Creek, were identified and documented. A total of 518 people attended the educational programs, and over 
Table 4. Total acreage in each of the Calleguas Creek watershed stream reaches in which best management practices (BMPs) were implemented from May 2009 to Mar. 2012 based on surveys conducted with growers and landowners during this time period. ${ }^{2}$

\begin{tabular}{|c|c|c|c|c|c|c|c|c|c|}
\hline $\mathrm{BMP}$ & $\begin{array}{c}\text { Mugu } \\
\text { Lagoon }\end{array}$ & $\begin{array}{c}\text { Calleguas } \\
\text { Creek } 2\end{array}$ & $\begin{array}{c}\text { Calleguas } \\
\text { Creek } 3\end{array}$ & $\begin{array}{c}\text { Revolon } \\
\text { Slough }\end{array}$ & $\begin{array}{c}\text { Beardsley } \\
\text { Channel }\end{array}$ & $\begin{array}{c}\text { Arroyo Las } \\
\text { Posas }\end{array}$ & $\begin{array}{r}\text { Conejo } \\
\text { Creek A }\end{array}$ & $\begin{array}{c}\text { Conejo } \\
\text { Creek B } \\
\end{array}$ & $\begin{array}{c}\text { Arroyo Santa } \\
\text { Rosa } \\
\end{array}$ \\
\hline Sediment and erosion & 365 & 368 & & 2,335 & 400 & 694 & & 50 & \\
\hline Irrigation & 260 & 25 & 9 & 4,251 & 1,007 & 959 & 53 & 98 & 8 \\
\hline Pest & & & & 1,656 & 444 & & & 48 & \\
\hline Nutrient & & & & 3,674 & 21 & & & & \\
\hline Property & & & & 2,120 & 23 & & & 48 & \\
\hline Total & 625 & 393 & 9 & 14,036 & 1,895 & 1,653 & 53 & 244 & 8 \\
\hline
\end{tabular}

${ }^{\mathrm{z}}$ Data are presented by BMP type. One property may have multiple implemented BMPs. Therefore, specific acres within a stream reach may be included in more than one type of BMP.

$90 \%$ of participants who completed evaluations rated the programs highly. In the final year of the project, $75 \%$ of attendees indicated they plan to implement new BMPs within the next 5 years, especially in the areas of irrigation, erosion, and pest management.

\section{Literature Cited}

California Regional Water Quality Control Board. 2013. Regional board FAQ about the conditional waiver program. Conditional waiver of waste discharge requirements for discharges from irrigated lands within the Los Angeles region. 25 Mar. 2013. <http://www.farmbureauvc. com/pdf_forms/ConditionalWaiver.pdf $>$.
California State Water Resources Control Board. 2013. 25 June 2013. <http://www.waterboards. ca.gov/water_issues/programs/land_disposal/ waste_discharge_requirements.shtml $>$.

Farm Bureau of Ventura County. 2013. Frequently asked questions about VCAILG and the conditional waiver. 25 June 2013. <http://www. farmbuereauvc.com/pdf_forms/FAQ_About_ VCAILG.pdf>.

Newman, J. 2011. 'New' ag waivers from two regional water quality control boards. UCNFA News 15:1-4. 17 June 2013. <http://ucanr.edu/ sites/UCNFAnews/Download_Newsletter_ $\mathrm{PDF} /$ ? newsitem $=29558>$.

State Water Resources Control Board. 2013. Irrigated lands regulatory program. $25 \mathrm{Mar} .2013 .<\mathrm{http}: / /$ www.swrcb.ca.gov/water_issues/programs/ agriculture/docs/about_agwaivers.pdf $>$.

U.S. Environmental Protection Agency (USEPA). 2013. Watershed assessment, tracking and environmental results. 14 June 2013. <http:// iaspub.epa.gov/waters10/attains_state.control? p_state $=$ CA\&p_cycle $=2010>$.

Ventura County Agriculture Irrigated Lands Group (VCAILG). 2008. 2007 Water quality management plan. 25 Mar. 2013. <http:// www.farmbureauvc.com/pdf_forms/water quality_plan_2007.pdf $>$.

Ventura County Agriculture Irrigated Lands Group (VCAILG). 2010. 2009 annual monitoring report. 25 Mar. 2013. <http://www.farmbureauvc. com/pdf_forms/2009_VCAILG_Report.pdf>. 